\title{
Six Years of Sick Leave Spells in a Group of University Civil Workers. Can Modern Work Bring Them a New Health Problem?
}

\author{
Adriano Dias ${ }^{1}{ }^{\oplus}$, João Marcos Bernardes ${ }^{1} \oplus$, Miriam Malacize Fantazia ${ }^{1}$, \\ Carlos Ruiz-Frutos ${ }^{2,4, *(\mathbb{D})}$ and Juan Gómez-Salgado ${ }^{3,4}$ (i) \\ 1 Public Health Grade Program, Botucatu Medical School, Paulista State University, Botucatu, \\ Sao Paulo 18618687, Brazil; dias.adriano@unesp.br (A.D.); jmbernardes@yahoo.com (J.M.B.); \\ adrianodiass@hotmail.com (M.M.F.) \\ 2 Department of Sociology, Social Work and Public Health, Universidad de Huelva, 21071 Huelva, Spain \\ 3 Department of Nursing, Universidad de Huelva, 21071 Huelva, Spain; jgsalgad@gmail.com \\ 4 Safety and Health Posgrade Program, Universidad Espíritu Santo, Samborondón, \\ Guayaquil 091650, Ecuador \\ * Correspondence: frutos@uhu.es; Tel.: +34-656407861
}

Received: 1 November 2018; Accepted: 19 December 2018; Published: 21 December 2018

check for updates

\begin{abstract}
The objective of this study is to analyse sick leave episodes of a university's collective of statutory workers in the State of São Paulo, between January 2010 and December 2015. For this, a descriptive study analysed 5776 registered spells of sick leave of four university units: agricultural sciences; human health, health and animal reproduction, and biological sciences; an administrative unit; and a university hospital. The medical expert assessment was carried out by general practitioners and psychiatrists who managed sick leave and return to work cases. Around 52\% had up to three sick leave episodes, and 10\% of the workers had 20 or more episodes. Each spell of sickness absence lasted a median of 30 days (IQR 8-60 days). Among all of sick leaves, 35\% had as a primary cause mental or behavioural diseases, of which $30 \%$ were depressive disorders, followed by around $18 \%$ related to the musculoskeletal system and the connective tissues. In the medical reports, $80 \%$ of the workers reported pain and $30 \%$ reported psychological symptoms. The collective, seen as privileged by many for their job stability, has a high percentage of sick leave due to mental illness, with extended periods which affect the levels of disability and reduce possibilities of return.
\end{abstract}

Keywords: sickness absence; public workers; university; psychosocial work environment; occupational health; health workers

\section{Introduction}

Sickness absence is a complex phenomenon that is strongly influenced by factors other than health [1-3]. It has been suggested that many workers will attend work with conditions that others will be absent with, and that where there are high rates of absence there are also high rates of "presenteeism". Many EU governments have introduced programmes aimed at encouraging long term absentees getting back into the workforce [1].

In Brazil, civil servants may be statutory or public employees. The former are holders of public office and are subject to statutory regimes established by the federal, state and local governments. On the other hand, the latter are subject to the rules of the Consolidation of Labour Laws (CLT), the decree that governs labour relations in Brazil [4].

In Brazilian public universities, the same rule coexists. However, the workers are divided into two other categories, technical-administrative and professors. Also, there may additional differences 
between the weekly work time, which may be full or part-time, and the type of dedication, exclusive or not. Thus, Brazilian universities have a multiplicity of worker types, not to mention outsourced workers, who deserve a separate analysis.

As many as $12 \%$ of Brazilian workers are civil servants, a similar proportion to some Latin American countries, but far from the percentages found in developed countries, where the average is $21 \%$, according to the Organization for Economic Co-operation and Development [5]. It is even further from some Scandinavian countries where more than a third of the economically active population is employed in the public service.

Even though working as a civil servant requires passing a civil service examination, it is highly desirable. This is due to the security and employment stability provided by the organisations, opportunities for professional formation and qualification, possibilities of professional advancement and salary increases through career plans and promotions, coverage of special pension regimes with higher pensions for lower contribution rates [6], while workers in the private sector tend to lead unemployment statistics. As a consequence of the higher level of education needed to be admitted to public service and its development during working years, more than half of civil servants have a higher education degree. On the other hand, in the private sector this percentage is $15 \%$ [7]. For example, more than $60 \%$ of the employees of a public university have a higher education degree, even though they occupy high school education level positions [8].

Although these benefits still exist or at least part of them, from the 1990s onwards and parallel to the transformations that occurred in business, the Government also reformed itself. It did so through a politico-ideological movement with economic roots, adopting management practices, until then typical of the private sector, and focusing on the search for quality and efficiency [9-13].

The changes in technical devices, management rules and the reorganisation of work environments resulted, for the workers, in an increase in qualification, workload and flexibility, in addition to the reduction of autonomy and remuneration. At the same time, this process accentuated competitive behaviours and disarticulated the capacity for social support, producing feelings of isolation and insecurity in employment [14,15]. In addition, the public service extinguished positions considered non-essential, allowing the hiring of outsourced workers (for a specific period of time, under different contract regimes and with unequal/lower salaries), of whom compliance with goals and an increase in pace and productivity was demanded [15].

A non-ideal work environment was generated as a result of all these changes, increasing psychosocial risk markers for workers' physical and mental health problems: excessive workloads, conflicting work demands, lack of clarity of function, lack of involvement in decision making and of influence on the way work is done, insecurity, ineffective communication and lack of social support from supervisors or colleagues [16,17]. These risk factors affected in quantity and intensity, what contrasts with the improvements in general health conditions of the world population in the same period [18] and, mainly, with the healthy worker effect [19].

The main indicator of workers' health problems is absenteeism [20], here defined as absence to work due to a disease and justified by a medical statement [21]. Studies on absenteeism in civil servants [22-27] indicate that the predominant disease is related to work activities and the professionals involved; and, also, that they are more frequent in female workers and in the age group between 30 and 45 years. Between 2003 and 2006, according to data from all civil servants employed by all departments and agencies related to the Government of São Paulo State (Southeast Brazil), nearly 200,000 sick leaves were granted each year, with mental disorders being responsible for almost $30 \%$ of these leaves [22].

In Brazil, official data [28] shows that mental disorders represent $10 \%$ of all pension benefits, being surpassed only by musculoskeletal disorders $(20 \%)$ and external causes $(25 \%)$. This is certainly resulting from the negative effects of these new work environments on workers' health.

In addition to the impact of absenteeism on productivity and interpersonal relationships at work, workers' illness often results in long-term sick leave. This implies difficulties in returning to work, 
mainly when it involves changes in job, function and the status derived from the limitations caused by the disease.

Thus, the objective of this study is to present an epidemiological profile of a university group of civil servants' sick leaves over a period of six years, as well as defining work characteristics and possible causes of sick leave.

\section{Materials and Methods}

\subsection{Study Design and Setting}

This is a descriptive study of sick leaves. Its population was composed of civil servants from a university located in inland São Paulo State, Brazil, that took sick leaves between the months of January 2010 and December 2015.

During the period that the information was collected by the University's Technical Section of Worker's Health, the university campus was composed by four academic units (agricultural sciences, human health, biological sciences and animal health and reproduction), an administration unit, and a university hospital.

\subsection{Participants}

The sum of the populations in these units, in the middle of the period (2012), was 4090 workers, among which about $60 \%$ were statutory civil servants, while the others were public employees subject to the CLT or outsourced public workers. The approximate proportional distribution of workers per unit, in the middle of the period, was: administration (5\%), agricultural sciences $(13 \%)$, human health and hospital (56\%), animal health (11\%), biological sciences (15\%).

During the six years of the study, 965 workers were examined by physicians, resulting in 5776 episodes of sick leaves, which comprised the study sample. It should be noted that the estimates of the populations made available from each year were fluctuating, which made it difficult to establish precise annual denominators and imposed the need to analyse the data globally.

The institution has its own occupational medical service, who examines all statutory workers who request a sick leave with duration of two days or more. This service is composed by general practitioners, who evaluate sick leave applications due to non-psychiatric morbidity, and psychiatrists, who evaluate sick leave applications due to mental disorders. The service not only manages all sick leaves applications, since it is the only one that can grant or deny them, but also all cases of readaptation to work.

\subsection{Variables and Data Sources}

For the exploratory phase of the study, data was extracted from two institutional databases: (a) Integrated Occupational Management Software (IOM) (UNESP, São Paulo, Brazil), which identifies the worker and stores physician's evaluation data; (b) Healthcare Medical System (HMS) (UNESP, São Paulo, Brazil), which records information about cases of work readaptation.

It is important to highlight that the two databases were not integrated or built under the same computational architecture (neither for research purposes), nor did it allow searches or information filtering (in the case of the HMS), which made it necessary to evaluate one by one all cases of work readaptation already made by that service to make them coincide with the valuations of the period.

Then, after retrieving and organising the information, a database was built. It contained variables of the following types: sociodemographic (place of birth, sex, current age and age when hired by the university, marital status and coexistence with partner), job characteristics (position, work unit, rehabilitation history, working time in the institution and total work time), sick leave characteristics (duration of each episode, number of medical evaluations in the period, total duration of all episodes, reason of the leave classified by the International Classification of Diseases (ICD-10) and behaviour of repeated sick leaves) and work readaptation (if it happened, time passed until it happened and if it resulted in any limitations). The reason for each sick leave was defined as the first or main diagnosis 
pointed by the physician, since it could have multiple reasons. Thus, it was necessary to create data mining tools to search for the reason of each leave and for variables related to the physicians' evaluations (type of injury, affected part and presence of psychological symptoms) in the IOM, a textual qualitative record base.

\subsection{Statistical Analysis}

The variables were analysed using simple and cumulative percentage distributions and measures of central tendency and dispersion (for discrete and continuous variables, respectively), using IBM SPSS software, v.20.0 (IBM, Armonk, NY, USA).

\subsection{Ethical and Legal Aspects}

The research has been carried out with the consent and support of the Human Resources of the units involved and was approved by the Ethics Committee of the Botucatu Medical School (protocol 1.874.625, of 12/19/2016).

\section{Results}

A total of 5776 spells of sick leave, of two or more days, from 965 workers, were studied. Table 1 shows that workers who took a sick leave had been hired by the university at a young age (28.6 \pm 6.7 years), but they had been in the institution for a long time (21.1 \pm 7.6 years) before taking the first sick leave during the period studied.

Table 1. Sociodemographic and working characteristics of the study population $(n=965)$.

\begin{tabular}{|c|c|c|c|c|c|}
\hline & Mean & Min. & p25 & Median & $\overline{\text { p75 }}$ \\
\hline Age started working at university & 28.65 & 18.35 & 23.07 & 27.84 & 33.10 \\
\hline \multirow[t]{2}{*}{ Time working at university } & 21.12 & 50.39 & 17.02 & 21.73 & 25.99 \\
\hline & & & $\mathrm{n}$ & $\%$ & $\mathrm{C} \%$ * \\
\hline \multirow[t]{2}{*}{ Sex } & \multicolumn{2}{|c|}{ Female } & 605 & 62.7 & 62.7 \\
\hline & \multicolumn{2}{|c|}{ Male } & 360 & 37.3 & 100.0 \\
\hline \multirow[t]{5}{*}{ Marital status } & \multicolumn{2}{|c|}{ Married } & 538 & 55.8 & 55.8 \\
\hline & \multicolumn{2}{|c|}{ Separated } & 232 & 24.0 & 79.8 \\
\hline & \multicolumn{2}{|c|}{ Divorced } & 132 & 13.7 & 93.5 \\
\hline & \multicolumn{2}{|c|}{ Single } & 57 & 5.9 & 99.4 \\
\hline & \multicolumn{2}{|c|}{ Widowed } & 6 & 0.6 & 100.0 \\
\hline \multirow{2}{*}{ Has a partner } & \multicolumn{2}{|c|}{ Yes } & 538 & 55.8 & 55.8 \\
\hline & \multicolumn{2}{|c|}{ No } & 427 & 44.2 & 100.0 \\
\hline \multirow[t]{2}{*}{ Origin } & \multicolumn{2}{|c|}{ São Paulo } & 952 & 98.7 & 98.7 \\
\hline & \multicolumn{2}{|c|}{ Another state } & 13 & 1.3 & 100.0 \\
\hline \multirow[t]{5}{*}{ Unit } & \multicolumn{2}{|c|}{ Administration } & 41 & 4.2 & 4.2 \\
\hline & \multicolumn{2}{|c|}{ Agricultural sciences } & 61 & 6.3 & 10.6 \\
\hline & \multicolumn{2}{|c|}{ Human health } & 748 & 77.5 & 88.1 \\
\hline & \multicolumn{2}{|c|}{ Animal health } & 56 & 5.8 & 93.9 \\
\hline & \multicolumn{2}{|c|}{ Biological sciences } & 59 & 6.1 & 100.0 \\
\hline \multirow[t]{13}{*}{ Position } & \multicolumn{2}{|c|}{ Mid-level healthcare } & 374 & 38.8 & 38.8 \\
\hline & \multicolumn{2}{|c|}{ Administration } & 143 & 14.8 & 53.6 \\
\hline & \multicolumn{2}{|c|}{ Operational } & 119 & 12.3 & 65.9 \\
\hline & \multicolumn{2}{|c|}{ Academic support } & 72 & 7.5 & 73.4 \\
\hline & \multicolumn{2}{|c|}{ High-level healthcare } & 61 & 6.3 & 79.7 \\
\hline & \multicolumn{2}{|c|}{ Teaching } & 54 & 5.6 & 85.3 \\
\hline & \multicolumn{2}{|c|}{ Rural work } & 45 & 4.7 & 89.9 \\
\hline & Others & gh-level & 22 & 2.3 & 92.2 \\
\hline & Supervisior & nd reception & 22 & 2.3 & 94.5 \\
\hline & Others & id-level & 16 & 1.7 & 96.2 \\
\hline & Sup & visor & 15 & 1.6 & 97.7 \\
\hline & Radic & erapy & 13 & 1.3 & 99.1 \\
\hline & Tra & port & 9 & 0.9 & 100.0 \\
\hline
\end{tabular}

* cumulative percentage. 
The majority were women (62.7\%), lived with a partner (55.8\%) and born in the State of São Paulo $(98.7 \%)$. The largest proportion of workers belonged to the Human Health university unit $(77.5 \%)$ and occupied mid-level healthcare positions (38.8\%).

Table 2 shows that the population had, on average, about 50 years of age when they took the sick leave and that the average total duration of the sick leave per worker was 564 days, varying between 15 to more than 6 thousand days, distributed in single $(23.5 \%)$ and multiple $(76.5 \%)$ leaves. It should be highlighted that $23.5 \%$ and $17 \%$ of the workers had had one and two spells of sick leave, respectively, and almost $80 \%$ of the workers had up to 10 episodes during the study period. $10 \%$ had 20 or more, reaching a maximum of 59. Each spell of sick leave $(n=5776)$ had a median length of absence of 30 days (IQR 8-60 days), with minimums and maximums of 2 and 1439 days, respectively.

Table 2. Characteristics of sick leaves.

\begin{tabular}{|c|c|c|c|c|c|c|c|}
\hline & Mean & SD & Min. & Max. & p25 & Median & p75 \\
\hline Age at the start of the process $(n=965) \#$ & 49.77 & 7.67 & 25.58 & 81.61 & 45.28 & 50.01 & 54.68 \\
\hline Total length of absence in days $(n=965)$ & 564.47 & 1053.95 & 15.00 & 6077.00 & 79.00 & 147.00 & 351.00 \\
\hline Time until readaptation in days $(\mathrm{n}=239)$ & 343.24 & 684.99 & 2.00 & 5925.00 & 15.00 & 60.00 & 290.50 \\
\hline Each sick leave spell length of absence $(n=5776)$ & & & & & $\mathrm{n}$ & $\%$ & \% cum. \\
\hline Readaptation $(\mathrm{n}=965)$ & \multicolumn{3}{|c|}{ No } & & 714 & 74.0 & 74.0 \\
\hline Readaptation with limitations $(\mathrm{n}=251)$ & \multicolumn{3}{|c|}{ Yes } & & 195 & 77.7 & 100.0 \\
\hline \multirow{4}{*}{ Number of medical evaluations in the period $(n=965)$} & \multicolumn{3}{|c|}{1} & & 227 & 23.5 & 23.5 \\
\hline & \multicolumn{3}{|c|}{2} & & 162 & 16.8 & 40.3 \\
\hline & \multicolumn{3}{|c|}{3} & & 111 & 11.5 & 51.8 \\
\hline & \multicolumn{3}{|c|}{4} & & 73 & 7.6 & 59.4 \\
\hline \multirow{14}{*}{ ICD-10 chapter $(n=5776) *$} & \multicolumn{3}{|c|}{ I } & & 130 & 2.3 & 2.3 \\
\hline & \multicolumn{3}{|c|}{ II } & & 219 & 3.8 & 6.0 \\
\hline & \multicolumn{3}{|c|}{ III } & & 13 & 0.2 & 6.3 \\
\hline & \multicolumn{3}{|c|}{ IV } & & 83 & 1.4 & 7.7 \\
\hline & \multicolumn{3}{|c|}{$\mathrm{V}$} & & 2022 & 35.0 & 42.7 \\
\hline & & $\mathrm{V}$ & & & 131 & 2.3 & 45.0 \\
\hline & & V & & & 215 & 3.7 & 48.7 \\
\hline & & VI & & & 48 & 0.8 & 49.5 \\
\hline & & $\mathrm{I}\rangle$ & & & 245 & 4.2 & 53.8 \\
\hline & & $x$ & & & 182 & 3.2 & 56.9 \\
\hline & & XV & & & 89 & 1.5 & 84.9 \\
\hline & & XI & & & 362 & 6.3 & 91.1 \\
\hline & & $X$ & & & 25 & 0.4 & 91.6 \\
\hline & & $X>$ & & & 487 & 8.4 & 100.0 \\
\hline Iniured hodv part $(n-1018) * *$ & & Tru & & & 228 & 22.4 & 22.4 \\
\hline Injured body part $(n=1018)$ & & Har & & & 162 & 15.9 & 38.3 \\
\hline & & Ey & & & 151 & 14.8 & 53.1 \\
\hline & & $\mathrm{Fe}$ & & & 130 & 12.8 & 65.9 \\
\hline & & Arr & & & 124 & 12.2 & 78.1 \\
\hline & & Le & & & 99 & 9.7 & 87.8 \\
\hline & & $\mathrm{He}$ & & & 87 & 8.5 & 96.4 \\
\hline & & Fing & ers & & 37 & 3.6 & 100.0 \\
\hline
\end{tabular}


Table 2. Cont.

\begin{tabular}{|c|c|c|c|c|c|c|}
\hline & Mean & Min. & Max. & p25 & Median & p75 \\
\hline \multirow{4}{*}{ Type of injury $(n=1385) * *$} & & Pain & & 1112 & 80.3 & 80.3 \\
\hline & & Contusion & & 55 & 4.0 & 94.4 \\
\hline & & Burn & & 17 & 1.2 & 98.2 \\
\hline & & Sharp-cutting & & 15 & 1.1 & 99.3 \\
\hline \multirow{2}{*}{ Psychological symptoms $(n=5776) * *$} & & No & & 4044 & 70.0 & 70.0 \\
\hline & & Yes & & 1732 & 30.0 & 100.0 \\
\hline \multirow{2}{*}{$\begin{array}{l}\text { Symptoms start with other chapter and change to chapter } \\
\text { V of the ICD-10 until } 20^{\text {th }} \text { expert record }(n=965)\end{array}$} & & No & & 768 & 79.6 & 79.6 \\
\hline & & Yes & & 197 & 20.4 & 100.0 \\
\hline $\begin{array}{l}\text { Symptoms start with chapter V of the ICD-10 and is kept } \\
\text { until } 20^{\text {th }} \text { expert record }(n=965)\end{array}$ & & No & & 740 & 76.7 & 76.7 \\
\hline
\end{tabular}

\# Refers to the worker's age at the first sick leave spell during the study period. ${ }^{*} \mathrm{I}$-Certain infectious and parasitic diseases; II-Tumours (Neoplasms); III-Diseases of the blood and blood-forming organs and certain disorders involving the immune mechanism; IV—Endocrine, nutritional and metabolic diseases; V-Mental and behavioural disorders; VI-Diseases of the nervous system; VII—Diseases of the eye, adnexa. VIII-Diseases of the ear and mastoid process; IX-Diseases of the circulatory system; X-Diseases of the respiratory system; XI—Diseases of the digestive system; XII—Diseases of the skin and subcutaneous tissue; XIII—Diseases of the musculoskeletal system and connective tissue. XIV-Diseases of the genitourinary system; XV-Pregnancy, childbirth and the puerperium; XVI - Certain conditions originating in the perinatal period; XVII-Congenital malformations, deformations and chromosomal abnormalities; XVIII-Symptoms, signs and abnormal clinical and laboratory findings, not elsewhere classified; XIX-Injury, poisoning and certain other consequences of external causes; XX-External causes of morbidity and mortality; XXI-Factors influencing health status and contact with health services. ${ }^{* *}$ Referred to by the doctor-expert in the record (based on complaints) of the consultation and extracted from the text.

More than one third (35\%) of all sick leaves had, as primary (or main) cause, diseases classified as mental or behavioural disorders, according to the ICD-10 [29]. These were followed at a distance by diseases of the musculoskeletal system and of the connective tissue (17.8\%). According to the medical evaluations, $20 \%$ of all cases affected the trunk; there was pain in up to $80 \%$ of the episodes; and there was psychological symptomatology in $30 \%$ of all cases.

Regarding the main cause according to the ICD-10, considering up to the $20^{\text {th }}$ episode of sick leave (91.5\% of cases), the cause of the first episode was modified in subsequent events in $45 \%$ of the cases, and it may have or not returned to the cause of the first episode. The main cause was subsequently modified to a diagnosis included in the chapter 'Mental and behavioural disorders' from the ICD-10 in $20 \%$ of the sick leaves that did not have a mental disorder as the main cause in the first episode. And, in about $23 \%$ of the cases, mental disorders were the main cause from the beginning until the end of the follow-up.

Table 2 shows that $26 \%$ (239) of the 965 workers who took a sick leave had to be readapted to work, with an average waiting period of 344 days. Of these, $77.7 \%$ (195) were readapted with some degree of activities' limitation when returning to work.

Table 3 presents the 51 most frequent causes of sick leave among the 150 diseases that were registered as the main cause in the period studied and that represent $90.1 \%$ of the total causes. Among the mental and behavioural disorders (Chapter V of the ICD-10), we see depressive disorders and the use of psychoactive substances as those that were most frequently recorded. Meantime, among the osteomuscular diseases (Chapter XIII of the ICD-10), dorsalgias, arthropathies and shoulder diseases were the most frequent. The other 99 diseases corresponded to $9.9 \%$ of the events among the 5776 registered spells of sick leave. 
Table 3. Main causes of 5776 sick leaves (ICD diagnosis code or range).

\begin{tabular}{|c|c|c|c|c|}
\hline P. ${ }^{*}$ & ICD Diagnosis Code or Range & $\mathbf{n}$ & $\%$ & $\mathrm{C}^{*}{ }^{* *}$ \\
\hline 3 & Dorsalgia & 547 & 9.5 & 40.0 \\
\hline 5 & Shoulder lesions & 254 & 4.4 & 51.6 \\
\hline 6 & Disorder of conjunctiva & 159 & 2.8 & 54.3 \\
\hline 7 & Malignant neoplasm & 158 & 2.7 & 57.0 \\
\hline 9 & Arthropathies & 103 & 1.8 & 61.1 \\
\hline 10 & Injuries of the knee and leg & 96 & 1.7 & 62.8 \\
\hline 11 & Personality and behavioural disorders & 81 & 1.4 & 64.2 \\
\hline 12 & Diseases of the veins and vessels and lymph nodes & 80 & 1.4 & 65.6 \\
\hline 13 & Injuries of the ankle and foot & 79 & 1.4 & 66.9 \\
\hline 14 & Other joint disorders & 72 & 1.2 & 68.2 \\
\hline 19 & Benign neoplasm & 53 & 0.9 & 73.1 \\
\hline 20 & Diabetes Mellitus & 51 & 0.9 & 74.0 \\
\hline 21 & Calculus of kidney & 49 & 0.8 & 74.8 \\
\hline 22 & Disorders of the gallbladder, biliary tract and pancreas & 49 & 0.8 & 75.7 \\
\hline 23 & Influenza (flu) and pneumonia & 48 & 0.8 & 76.5 \\
\hline 24 & Hypertensive diseases & 45 & 0.8 & 77.3 \\
\hline 25 & Diseases of the inner ear & 36 & 0.6 & 77.9 \\
\hline 26 & Other local skin and subcutaneous tissue infections & 36 & 0.6 & 78.5 \\
\hline 27 & Chronic diseases of the lower respiratory tract & 32 & 0.6 & 79.1 \\
\hline 28 & Episodic and paroxysmal disorders & 32 & 0.6 & 79.6 \\
\hline 29 & Pain and other conditions related to the female genital organs and the menstrual cycle & 32 & 0.6 & 80.2 \\
\hline 37 & Other diseases of the urinary system & 26 & 0.5 & 84.0 \\
\hline 38 & Other diseases of the intestines & 26 & 0.5 & 84.4 \\
\hline 39 & Symptoms and general signs & 26 & 0.5 & 84.9 \\
\hline 40 & Cerebrovascular diseases & 24 & 0.4 & 85.3 \\
\hline 41 & Other viral diseases & 24 & 0.4 & 85.7 \\
\hline 42 & Other forms of heart disease & 24 & 0.4 & 86.1 \\
\hline 43 & Hernia & 23 & 0.4 & 86.5 \\
\hline 44 & Organic mental disorders, including symptomatic disorders & 22 & 0.4 & 86.9 \\
\hline 45 & Injuries of the forearm and elbow & 22 & 0.4 & 87.3 \\
\hline 46 & Injuries of the shoulder and arm & 22 & 0.4 & 87.7 \\
\hline 47 & Schizophrenia, schizotypal disorders and delusional disorders & 21 & 0.4 & 88.0 \\
\hline 48 & Other bacterial diseases & 20 & 0.3 & 88.4 \\
\hline 49 & Viral fevers transmitted by arthropods and hemorrhagic viral fevers & 19 & 0.3 & 88.7 \\
\hline 50 & Obesity and other types of hyperalimentation & 18 & 0.3 & 89.0 \\
\hline \multirow[t]{3}{*}{51} & Other external causes of accidental injuries and falls & 17 & 0.3 & 89.3 \\
\hline & Other (99 categories) & 617 & 10.7 & 100 \\
\hline & Total & 5776 & 100 & \\
\hline
\end{tabular}

* Position; ${ }^{* *}$ Cumulative percentage.

\section{Discussion}

First of all, it should be highlighted that the databases accessed to obtain the information used in this research contained data only on the civil servants who took at least one spell of sick leave during the study's period. Therefore, our results and their interpretation are valid only to this particular group of individuals and cannot be generalised to university civil servants in general.

The present study allows us to describe sick leave causes in a group of great importance because of its number and that is not usually studied, such as public university workers. This is a group of workers seen by many as privileged in terms of psychosocial risk protection due to their special work 
regime (for the most part of them), their job stability [30] and/or their educational levels above the average [7]. We identified a high percentage of sick leaves related to mental disorders (35\%), of which $30 \%$ are depressive disorders. Having data on the causes, frequency and duration of sick leaves makes it possible to propose preventive measures related to organisational factors and aimed at improving the management of health services at these public institutions.

It must be borne in mind that the results presented in this study refer only to a subgroup of civil servants, statutory workers. However, the fact that the results show that workers with a medium level of education are the ones who take more sick leaves seems to corroborate the statement of health protection for that kind of worker. At the same time, it should be considered that these workers occupy lower positions in the employment hierarchy and perform less flexible activities, while those with a higher level of education tend to occupy management positions. These positions are frequently more flexible, and may be able to make use of informal agreements. Thus, their sick leaves may be under-registered in the system.

When a civil servant (regulated by statute or specific regulation, contributor of a provisional regime that belongs to an administrative unit, whether federal, state or municipal) requests a sick leave, he/she undergoes a medical expert examination that aims at the social and financial equilibrium of the institutions [31]. This study was conducted at an institution where the medical evaluations of sick leave are made by physicians who depend on the same employer of the workers they examine. This could mean that their decisions may not correspond to the reality of the diseased workers, for example, anticipating times of return to work. Although the medical evaluations carried out by these professionals may induce doubts, it is evident that the centralisation of these evaluations at the institution's own occupational medical service leads not only to reductions of travels to undergo examinations, but also facilitate the standardisation of criteria [32].

The expected work time until a worker takes a sick leave should be in accordance with the life cycle, in other words, older workers should be more likely to take sick leaves. This statement is corroborated in the present study, in which we see that $76 \%$ of workers were over 46 years of age and the average time they had spent in the institution until the first sick leave was over 21 years. However, other international studies on sick leaves due to non-work directly related causes show that this proportion is less than $30 \%$ [33].

Another finding of this research is that almost two thirds of the workers who took a sick leave were women, while in other scenarios women were less than $50 \%$ [33]. Consideration should be given to sex discrimination, which could influence the distribution of medium and higher education positions and its relation to the frequency of sick leaves. Although when analysing only sick leave cases without having the denominator of exposed workers, we cannot affirm that the proportion in one of the two sexes is greater or not. Likewise, it is well known from previous studies that women must attend to family emergencies to a greater extent than men, and this generates a higher percentage of sick leaves because there is no other mechanism that allows an individual to take care of children or other family members when such events arise [34].

The university unit with the highest proportion of sick leaves was the Human Health one (77.5\%), in equal percentage to the proportion of workers of the Faculty of Medicine, and the university hospital accounted for $73 \%$ of those who composed this study's sample. It should be highlighted that almost half of the sick leaves were taken by health care workers, a fact that corroborates that, due to risks ranging from biological to organisational type [35-37], they are a population of workers quite vulnerable to temporary incapacities for work.

Making a reflection on the two previous considerations, the higher prevalence of workers from the Human Health unit can also determine the higher incidence of sick leaves among women, since the majority of the workers in the health sector are females, as stated by international and Brazilian literature [38-40].

The average duration of sick leaves for each worker probably varies in function of age, the type of work carried out and seriousness of the disease, associations that were not analysed since this is a 
descriptive study. However, it is necessary to highlight the multiplicity of events that the same worker can have, since $77 \%$ of the workers had more than one episode of sick leave in the study period and, of these, $45 \%$ had repeated episodes, maintaining the main cause from the first to the last episode. That is to say, it is very possible to infer tendencies of chronification of the diseases that originated the sick leaves, although they can also be explained, in part, by the greater age of the studied workers. However, to corroborate these hypotheses, no studies were found that had investigated predictors of the multiplicity of sick leaves.

Analysing chronic diseases, if we assume that longer sick leaves are a good example, we observe that these occurred to a greater extent among mental and behavioural diseases. This is consistent with the natural history of these diseases given that this type of pathologies produces acute symptoms to a lesser extent, except in some cases such as depressive disorders. However, if we analyse the records of the medical evaluations in less than a third of the registered sick leaves, psychological symptoms were identified as a complaint.

On the other hand, the same medical evaluation reports (when based on the initial complaints) that initially did not corroborate the diagnoses of the causes of temporary incapacity for work, now revealed that pain was present in $80 \%$ of all events. Thus, it is a widely found symptom in the majority of the acute causes that originated temporary incapacities for work, although they can also become chronic.

The finding that more than a third of the sick leaves had as their main cause mental and behavioural diseases is an important warning, especially because it does not agree with other populational studies [28]. In these, they are the fourth cause (and very close to the fifth), with a percentage close to $9 \%$ of the total. This was not either in accordance with other European studies where this group of diseases is the fifth cause and accounts for less than $8 \%$ of the sick leave total, behind musculoskeletal, respiratory, infectious diseases or those grouped in chapters XIX and XX of the ICD-10, generically described as external causes [32,33].

Depressive disorders were the most prevalent among all registered illnesses and one fifth of the workers had a main diagnosis related to mental health throughout their sick leave history. These results are congruent with previous studies [41] and can be explained by several reasons, which may also interact. We see how the mental health of civil servants is worse than that of the workers of the private sector. This leads us to believe that the recent changes in management mechanisms and work organisation that the civil sector has been through have led to work organisation models typical of the private initiative, based on productivity, which may impact more significantly on civil servants than in other sectors.

Another possible explanation is that the presence of psychiatrists among the physicians that work in the institution's own occupational medical service could lead to a better diagnosis or overdiagnosis of mental and behavioural diseases. It has been described, in previous publications, that the presence of such specialists can increase the diagnoses of mental illnesses and that such inadequate diagnoses and treatments can increase the risk for the said persons to develop physical disorders such as diabetes, cardiac disorders, weight gain, and other potentially serious health conditions [42].

In any case, due to overdiagnosis or not, addictions as a consequence of mental and behavioural disorders imply a large number of sick leaves to require medical treatment, in addition to great personal, institutional, economic and social losses, such as those derived from absenteeism, reduction of work ability and loss of productivity $[15,22,26]$. Substance addiction is also associated with jobs with high psychological demands and low work control $[43,44]$, and the high prevalence obtained in this study can indicate that the work environment in the university presents such negative characteristics to workers' mental health.

There is consensus on the high cost of mental illness attributed to the loss of productivity and measured as absenteeism or lost work days. Thus, it is advisable to open lines of research that allow us to better understand the incidence, extent and recurrence of this type of diseases in this workers' population [45]. 
A large number of workers needed a readaptation of their previous work activity and, for many of them, with limitations. This aspect is important because we know from bibliography that the longer the duration of the sick leave the more it is related to the degree of disability and the lower the probability of returning to their original job [46].

\section{Strength and Limitations}

There are some limitations in this study. First, sick-leaves are multi-factorial and influenced not only by the health status of the individuals, but also by their work environment, social and psychological factors [47], attitudes and commitment to work as well as social insurance system. Thus, since the medical reports mainly contained health related information, we cannot make inferences about other possible sick leave causes related, for example, to psychosocial and workplace factors.

Second, it is a common problem for many registry-based studies of sick leaves that they only have access to one diagnosis, while we know that workers often struggle with several complaints and illnesses. Unfortunately, this was also the case of the databases that we had access to. They did not contain all the information we consider relevant, such as all the diagnoses related to each sick leave spell. In the system, only the main diagnosis of each sick leave spell is recorded. To identify all the workers with multiple complaints and their diagnoses, access to the medical records of each worker would be needed. However, we did not have access to these documents.

Third, we did not have access to the total number of workers at the units, forbidding the possibility to establish a denominator for the amount of sick leaves. This is a clear limitation, as it precludes us to know e.g. the overall prevalence and/or incidence of sick leaves in the units or to what extent the distributions of the various sociodemographic and work characteristics mirror that of the working population as a whole. The total number of workers at the units was not known, since it was fluctuating (due to hiring, layoffs, transfers and retirements), both during the entire study period and yearly. This made it difficult, if not almost impossible, to establish a precise estimation of the workers' population (needed denominator for prevalence and incidence calculation), and the decision to run an overall analysis of the entire six-year period made it even harder. A possible solution would be to use the number of workers recorded in the middle of 2012 (2364). However, this would bring even more inaccuracies and lead to the stratification of the analysis year by year, what would end up determining an annual analysis. Fourth, our results may be conditioned by the fact that the medical evaluations of sick leaves are made by physicians that work in the same university institution, being able to speed the return to work. However, a strength related to this centralisation of the evaluations, by the institution's own occupational medical service, is the standardisation of criteria.

The main difficulty to perform this study was that both databases were not integrated or built under the same computational architecture. This fact forced us to build the database used in the study manually, which was time-consuming and required extensive effort to collect information. These databases also presented most of the five methodological problems regarding the analysis of sickness absence described by Hensing et al. [48]. Solving these problems would facilitate the use of this useful source of information, not only for research purposes but also for the follow-up of sick leaves by the occupational medical service in the future.

\section{Conclusions}

Around $90 \%$ of all spells of sick leave were due to mental illness and musculoskeletal disorders. We would highlight that, when compared with other groups of sick workers, they have a higher number of sick leave spells due to mental illnesses, mostly depressive disorders. This fact has a negative effect on the workers involved and higher costs for the university. This is because they are a type of sick leave associated with higher levels of disability, fewer possibilities of return to work and that needs a process of readaptation to the previous job position. From a practical perspective, these results are of great relevance for those involved with workers' health management: they allow an overview of the diseases that are related to sick leaves in university workers, their burden, and 
also the widening of Occupational Health and Safety (OSH) managers' understanding about workers' sociodemographic data relation with sick leaves and return to work. Furthermore, the results might guide the construction of a workplace's preventive and protective measures and of health promotion interventions to reduce the burden on workers' health.

Using both record databases (Integrated Occupational Management Software and Health Medical System) to acquire the data used in this paper has allowed us to identify some points that must be improved in order to achieve the full potential of these tools, such as the absence of important data, the use of different computational architecture for both databases and the need of linkage between them. But this is not all, they have allowed us to demonstrate the usefulness of these databases for better sick leaves management by OSH managers and workers.

The analysis of data on sickness absences stored in computerised databases can lead to the detection of failures in the management system, the identification of groups, pathologies and organisational measures where action is needed. An example is the greater vulnerability found in the "Human health" unit that can be explained by being composed mostly by females and health personnel, two of the variables that in previous studies have been associated with a greater number of sick leave spells.

Finally, the effort to extract the data from both databases and reconstruct it under a unified database will contribute for OSH researchers and workers in concomitant and/or subsequent studies. With these, we intend to investigate some hypotheses that were generated during this study regarding predictors of multiple spells of sick leaves. For example, the ageing of the workforce due to not replacing retired workers and the effects of the economic crisis.

To conclude, the studied sick leaves taken by the university workers differ from those presented in previous publications, since more than a third of the sick leaves had as their main cause mental and behavioural diseases, also because women comprised almost two-thirds of the workers who took a sick leave and due to the fact that $76 \%$ of the workers who took a sick leave were over 46 years old, as previously stated in the discussion. Furthermore, the long duration of the sick leaves found in this study is remarkable and it may be related to the fact that multiple repetition of events occurred in several cases.

We would also like to highlight the important contingent of workers that were readapted to their previous work activity and the high percentage of those who were readapted to work with limitations. This is important since it is well known that the longer the sick leave is, the higher the disability levels and the lower the chances of return to work.

Author Contributions: Conceptualisation, A.D., J.M.B., M.M.F., C.R.-F. and J.G.-S.; Data curation, A.D., J.M.B., M.M.F., C.R.-F. and J.G.-S.; Formal analysis, A.D., J.M.B., M.M.F., C.R.-F. and J.G.-S.; Funding acquisition, A.D.; Investigation, A.D.; Methodology, A.D., J.M.B., M.M.F., C.R.-F. and J.G.-S.; Project administration, A.D.; Resources, A.D., J.M.B., M.M.F., C.R.-F. and J.G.-S.; Software, A.D., J.M.B., M.M.F., C.R.-F. and J.G.-S.; Supervision, A.D.; Validation, A.D. and J.M.B.; Visualisation, M.M.F., C.R.-F. and J.G.-S.; Writing—original draft, A.D., J.M.B., M.M.F., C.R.-F. and J.G.-S.

Funding: The São Paulo Research Foundation-FAPESP, process 2016-23096-1.

Acknowledgments: Botucatu Medical School/Research Unit of Public Health, Sandro Augusto Servilha Coquemala, Pedro Casagrande.

Conflicts of Interest: The authors declare no conflict of interests.

\section{References}

1. Whitaker, S. The management of sickness absence. Occup. Environ. Med. 2001, 58, 420-424. [CrossRef] [PubMed]

2. Marmot, M.G.; Rose, G.; Shipley, M.; Hamilton, P.J. Employment grade and coronary heart disease in British civil servants. J. Epidemiol. Community Health 1978, 32, 244-249. [CrossRef] 
3. Johnson, W.; Bell, J.A.; Robson, E.; Norris, T.; Kivimäki, M.; Hamer, M. Do worse baseline risk factors explain the association of healthy, obesity with increased mortality risk? Whitehall II Study. Int. J. Obes. 2018. [CrossRef]

4. Di Pietro, M.S.Z. Direito Administrativo, 29a ed.; GEN-Forense: São Paulo, Brazil, 2016.

5. Organization for Economic Cooperation and Development. Government at a Glance; Organization for Economic Cooperation and Development: Paris, France, 2015.

6. Ribeiro, C.V.S.; Mancebo, D. O servidor público no mundo do trabalho do século XXI. Psicol. Ciênc. Prof. 2013, 33, 192-207. [CrossRef]

7. Firpo, S. Emprego público protege quem não precisa. Folha de São Paulo. 2017. Available online: http:/ / www1.folha.uol.com.br/mercado/2017/06/1893308-emprego-publico-protege-quem-naoprecisa.shtml (accessed on 25 October 2017).

8. Lacerda, J.A. Capacitação e o perfil dos servidores públicos: UM estudo descritivo de uma Universidade Federal mineira; UFL: Lavras, Brazil, 2013.

9. Carinhato, P.H. Neoliberalismo. reforma do estado e políticas sociais nas últimas décadas do século XX no Brasil. Aurora 2008, 2, 37-46.

10. Franco, T.; Druck, G.; Seligmann-Silva, E. As novas relações de trabalho. o desgaste mental do trabalhador e os transtornos mentais no trabalho precarizado. Rev. Bras. Saude Ocup. 2010, 35, 229-248. [CrossRef]

11. Silva, I.P. Neoliberalismo e as mudanças na estrutura do Estado: Ineficiência. cultura organizacional e hibridismo entre modelos de gestão. Rev. Ciênc. Tecnol. Humanid. do IFPE 2011, 3, 12-24.

12. Chiavegato Filho, L.G.; Navarro, V.L. A organização do trabalho em saúde em um contexto de precarização e avanço da ideologia gerencialista. In O Avesso do Trabalho III; Lourenço, E.A.S., Navarro, V.L., Eds.; Outras Expressões: São Paulo, Brazil, 2013; pp. 91-106.

13. Motta, P.R.M. O estado da arte da gestão pública. Rev. Adm. Emp. 2013, 53, 82-90. [CrossRef]

14. Metzger, J.L. Mudança Permanente: Fonte de penosidade no trabalho? Rev. Bras. Saude Ocup. 2011, 36, 12-24. [CrossRef]

15. Tonetto, E.S.; Prieb, S.A.M.; Tonetto, T.S. Os efeitos da reforma administrativa do estado sobre os servidores técnicos-administrativos da UFSM. Rev. Univ. Soc. 2011, 21, 54-61.

16. European Agency for Safety and Health at Work. Management of Psychosocial Risks at Work: An Analysis of the Findings of the European Survey of Enterprises on New and Emerging Risks (ESENER); Observatory, E.R., Ed.; Publications Office of the European Union: Luxembourg, 2012; p. 64.

17. Ravalier, J.M.; McVicar, A.; Munn-Giddings, C. Public service stress and burnout over 12 months. Occ. Med. 2014, 64, 521-523. [CrossRef] [PubMed]

18. Briner, R.B. ABC of work related disorders. Absence from work. BMJ 1996, 313, 874-877. [CrossRef] [PubMed]

19. Porta, M.; Greenland, S.; Hernán, M.; Silva, I.S. A Dictionary of Epidemiology, 6th ed.; Oxford University Press: Oxford, UK, 2014; 377p.

20. Kivimaki, M.; Head, J.; Ferrie, J.E.; Shipley, M.J.; Vahtera, J.; Marmot, M.G. Sickness absence as a global measure of health: Evidence from mortality in the Whitehall II prospective cohort study. Br. Med. J. 2003, 327, 364-368. [CrossRef] [PubMed]

21. Permanent Commission and International Association on Occupational Health. Sub-committee on absenteeism: Draft recommendations. Br. J. Ind. Med. 1973, 30, 402-403.

22. Cruz, C.R.B.; Shirassu, M.M.; Barbosa, P.L.Q.; Santana, A.M.R. Transtornos mentais como causa de absenteísmo entre servidores públicos em São Paulo. Rev. Psiq. Clin. 2011, 38, 265-266. [CrossRef]

23. Fantazia, M.M. Perfil do adoecimento dos trabalhadores de câmpus universitário do interior paulista: Análise dos dados de absenteísmo por motivo de doença; Universidade Estadual Paulista: Botucatu, Brazil, 2015.

24. Costa, F.M.; Vieira, M.A.; Sena, R.R. Absenteísmo relacionado a doenças entre membros da equipe de enfermagem de um hospital escola. Rev. Bras. Enferm. 2009, 69, 38-44. [CrossRef]

25. Andrade, T.B.; Souza, M.G.C.; Simões, M.P.C.; Andrade, F.B. Prevalência de absenteísmo entre trabalhadores do serviço público. Sci. Med. 2008, 18, 166-171.

26. Braga, L.C.; Carvalho, L.R.; Binder, M.C.P. Condições de trabalho e transtornos mentais comuns em trabalhadores da rede básica de saúde de Botucatu (SP). Ciênc. Saude Colet. 2010, 15, 1585-1596. [CrossRef] 
27. Braga, L.C.; Vendrameto, M.T. Perfil de afastamento do trabalho por motivo de doença entre profissionais de enfermagem de uma instituição de ensino superior no interior paulista; I Congresso Paulista de Medicina Legal e Perícias Médicas de São Paulo, APM: São Paulo, Brazil, 2012.

28. Brasil; Ministério da Fazenda; Secretaria de Previdência; Instituto Nacional do Seguro Social. Empresa de Tecnologia e Informações da Previdência; Anuário Estatístico da Previdência Social: Brasilia FD, Brazil, $2015 ;$ p. 918.

29. Organização Mundial da Saúde. CID-10 Classificação Estatística Internacional de Doenças e Problemas Relacionados à Saúde, 10a ed.; USP: São Paulo, Brazil, 1997.

30. Constituição da República Federativa do Brasil. Art. 41; IPSM: Brasilia FD, Brazil, 1988.

31. Nakano, S.M.S.; Rodrigues Filho, S.; Santos, I.C. Perícia Médica. In Nakano SMS; Braga, B.E., Ed.; Perícia Médica; CRM-GO: Goiânia, Brazil, 2007; pp. 31-46.

32. Cabanillas-Moruno, J.L.; Miner, M.G.; Gracia, J.M.L.; Doncel, J.D.V. Tiempo óptimo personalizado de incapacidad temporal por diagnóstico; Consejería de Salud y Bienestar Social de la Junta de Andalucía: Sevilla, Spain, 2012.

33. Torá-Rocamora, I.; Martínez, J.M.; Gimeno, D.; Alberti, C.; Jardí, J.; Manzanera, R.; Benavides, F.G.; Delclos, G. Assessment of the magnitude of geographical variations in the duration of non-work-related sickness absence by individual and contextual factors. Gac. Sanit. 2015, 29, 164-171. [CrossRef]

34. Blank, N.; Diderichsen, F. Short-term and long-term sick-leave in Sweden: Relationships with social circumstances. working conditions and gender. Scand. J. Soc. Med. 1995, 23, 265-272. [CrossRef]

35. Gianino, M.M.; Politano, G.; Scarmozzino, A.; Charrier, L.; Testa, M.; Giacomelli, S.; Benso, A.; Zotti, C.M. Estimation of sickness absenteeism among Italian healthcare workers during seasonal influenza epidemics. PLoS ONE 2017, 12. [CrossRef] [PubMed]

36. Andersen, L.N.; Juul-Kristensen, B.; Roessler, K.K.; Herborg, L.G.; Sorensen, T.L.; Sogaard, K. Efficacy of 'Tailored Physical Activity' in reducing sickness absence among health care workers: Design of a randomised controlled trial. BMC Public Health 2013, 13, 917. [CrossRef] [PubMed]

37. Moll, S.E. The web of silence: A qualitative case study of early intervention and support for healthcare workers with mental ill-health. BMC Public Health 2014, 14, 138. [CrossRef]

38. World Health Organization. Gender and Health Workforce Statistics; World Health Organization: Geneva, Switzerland, 2008.

39. McDonagh, K.J.; Bobrowski, P.; Hoss, M.A.K.; Paris, N.M.; Schulte, M. The leadership gap: Ensuring effective healthcare leadership requires inclusion of women at the top. Open J. Leadersh. 2014, 3, 20-29. [CrossRef]

40. Wermelinger, M.; Machado, M.H.; Tavares, M.D.F.L.; Oliveira, E.S.; Moysés, N.M.N. A força de trabalho do setor de saúde no Brasil: Focalizando a feminização. Divulg. Saude Debate 2010, 45, 55-71.

41. Dias, A.; Gómez-Salgado, J.; Bernardes, J.M.; Ruiz-Frutos, C. Factors Affecting Sick Leave Duration for Non-Work-Related Temporary Disabilities in Brazilian University Public Servants. Int. J. Environ. Res. Public Health 2018, 15, 2127. [CrossRef] [PubMed]

42. Caplan, P.J. They Say You're Crazy: How the World's Most Powerful Psychiatrists Decide Who's Normal; Perseus Books Group: New York, NY, USA, 1995; 358p.

43. Barbosa-Branco, A.; Bultmann, U.; Steenstra, I. Sickness benefit claims due to mental disorders in Brazil: Associations in a population-based study. Cad. Saude Publica 2012, 28, 1854-1866. [CrossRef] [PubMed]

44. Barbosa-Branco, A.; Souza, W.R.; Steenstra, I.A. Incidence of work and non-work-related disability claims in Brazil. Am. J. Ind. Med. 2011, 54, 858-871. [CrossRef] [PubMed]

45. Dewa, C.S.; Loong, D.; Bonato, S. Work outcomes of sickness absence related to mental disorders: A systematic literature review. BMJ Open 2014, 4, e005533. [CrossRef]

46. Vieira, E.R.; Albuquerque-Oliveira, P.R.; Barbosa-Branco, A. Work disability benefits due to musculoskeletal disorders among Brazilian private sector workers. BMJ Open 2011, 1, e000003. [CrossRef] 
47. Lu, C.Y.; Tsai, M.C.; Muo, C.H.; Kuo, Y.H.; Sung, F.C.; Wu, C.C. Personal, Psychosocial and Environmental Factors Related to Sick Building Syndrome in Official Employees of Taiwan. Int. J. Environ. Res. Public Health 2018, 15, 7. [CrossRef] [PubMed]

48. Hensing, G.; Alexanderson, K.; Allebeck, P.; Bjurulf, P. How to measure sickness absence? Literature review and suggestion of five basic measures. Scand. J. Soc. Med. 1998, 26, 133-144. [CrossRef] [PubMed]

(C) 2018 by the authors. Licensee MDPI, Basel, Switzerland. This article is an open access article distributed under the terms and conditions of the Creative Commons Attribution (CC BY) license (http:// creativecommons.org/licenses/by/4.0/). 